\title{
Comparison of revegetation techniques on mineral clay soil: analysis of quantitative response of vegetation cover
}

\author{
Enrico Muzzi, Gabriele Mongardi \\ Department of Agricultural Sciences, University of Bologna, Italy
}

\begin{abstract}
Revegetation of mineral-clay soils is a notably complex ecological and technically challenging undertaking that depends on substrate profile and local micro-environmental conditions, factors making it a particularly long procedure as well. This study compared and assessed the medium-term effectiveness of four treatments employed to promote stable pedogenesis and herbaceous recolonisation of abandoned clay quarries in the Apennine foothills of northern Italy's EmiliaRomagna region. The treatments included: slow-release $\mathrm{N}$ organic fertiliser, phosphate fertiliser, organic amendment and topsoil [the soil top layer $(0-0.2 \mathrm{~m})$ of a local natural meadow]. The state of the vegetative cover was monitored monthly from 1994 through 2004, until problems of slope stability at the site compromised the integrity of the trial plots. Significant effects were achieved by the recycled topsoil through 8 years and by organic amendment through 6 years; the effects of slow-release nitrogen were notably limited over time and phosphorous delivered a medium-term response but of notable year-toyear swings. No interactions among factors emerged in the mediumterm. After 11 years, treatments did not induce effects statistical appreciable. Our results suggest that the tested agronomic strategies on mineral clay soil did not trigger, in the medium-term, secondary succession processes able to potentially alter the spontaneous revegetation course.
\end{abstract}

Correspondence: Enrico Muzzi, Department of Agricultural Sciences, University of Bologna, viale Fanin 46, 40127 Bologna, Italy.

E-mail: enrico.muzzi@unibo.it

Key words: Reclamation; revegetation; clay; quarry; topsoil.

Acknowledgements: the authors thank Sibelco Italia S.p.a., whose financial and logistical support made this study possible, and Dario Giordano and Marco Garuti, for their unstinting help and expert engineering advice.

Conflict of interest: the authors declare no potential conflict of interest.

Received for publication: 27 November 2015.

Revision received: 28 April 2016.

Accepted for publication: 30 April 2016.

(C) Copyright E. Muzzi and G. Mongardi, 2016

Licensee PAGEPress, Italy

Italian Journal of Agronomy 2016; 11:723

doi:10.4081/ija.2016.723

This article is distributed under the terms of the Creative Commons Attribution Noncommercial License (by-nc 4.0) which permits any noncommercial use, distribution, and reproduction in any medium, provided the original author(s) and source are credited.

\section{Introduction}

Mining is the human activity with the highest impact on the environment. Not only the biological activity is completely annihilated, but even all the physic, chemical and micro-climatic characteristics of the site are strongly modified (Haigh, 2000). In Italy there are 21,367 censed quarries, 5592 of which are still in use (Legambiente, 2014). Most of the 16,045 inactive quarries are completely abandoned to spontaneous re-naturation processes. This abandonment generates pollution, erosion and landslides, which are big issues for landscape, environment and territory (Legambiente, 2014). Among all the quarries, clay ones presents the highest difficulty in reclamation, due to the long periods necessary to re-activate the biological processes. Most of these clay quarries are located in the Emilia-Romagna region, in the provinces of Reggio Emilia, Modena and Bologna (Northern Italy).

The years of the post-World War II in Emilia-Romagna region saw the growth of a thriving ceramic tile industry based in the foothills of the North Apennines in several provinces. The industry's success relied on quarrying supplies of mineral clays from widespread local deposits. Millions of cubic meters had been extracted up to the $1990 \mathrm{~s}$, but by then, innovations in manufacturing and shifting market demands led to the importing of raw materials from other domestic districts and foreign countries. Consequently, many local abandoned quarries need to be reclaimed (Montanari, 2012). Clay soil properties like micro-porosity, low air and water permeability, low seepage rate and strong compaction make vegetation establishment or succession and pedogenesis particularly long-term processes, even when only the uppermost soil layers are targeted.

These soil properties obviously constrain the range of applicable problem-solving techniques. On one hand, they have led researchers and industry consultants alike to a recycling of substrates present at the sites themselves. Indeed, pains-taking collecting, handling and reuse of original, naturally occurring horizons, including both top and subsoil layers, are now even being incorporated in the planning stages of new quarries (Schuman et al., 2000). This approach is based on the hard-won realisation that stewardship of a highly complex element like soil is the most effective means of promoting the rapid onset of the biological cycles needed for the dynamic processes of post-extraction reclamation and for the self-sustainability of the processes themselves (Haigh, 2000).

On the other hand, however, it is more often the case of having to address already compromised quarry areas whose original surface soil cannot be recovered either on site or even in sufficient volume from adjacent areas. There are also areas whose morphological conditions, like steep slopes, or former uses, like farming or pasture, have led to severe erosion and stripped soil profiles. It is thus neither possible nor conceivable in any of these conditions to procure surface horizons - up to $50 \mathrm{~cm}$ of topsoil and to $100 \mathrm{~cm}$ of subsoil - of adequate composition (Schuman et al., 2000). The absence of a topsoil layer, by affecting the physico-chemical soil properties, may promote soil compaction, structural instability, accelerated runoff, erosion, and may lead to soil toxi- 
city, weakened and depleted soil biological system, and infertility (Haigh, 2000).

Reclamation in these foothill areas has nearly always focused on reconstituting the environment (Baines, 1989; Muzzi and Rossi, 2003), i.e., reconstructing topsoil layers, fertility (Marrs and Gough, 1995) and vegetative cover (Hodgson, 1995) directly upon the mineral-clay substrate.

This includes site preparation to boost soil nutrient availability and biological activity with inputs of mineral elements (Koide and Mooney, 1987; Hume and August, 1988; Reeder and McGinnies, 1989; Mays et al., 2000), organic matter (Pesant and Vigneux, 1992; Schoenholtz et al., 1992) and mycorrhizal inoculum (Tate, 1985; Cockrell et al., 1993). These applications are designed to make the grass cover stable, to foster natural dynamics like vegetative succession (Redente and Depuit, 1988) and to defend the site against erosion (Morgan, 1986). This reconstructive approach has been applied in Emilia-Romagna region for many years, through agronomic practices such as fertilisations, tillage and amendments. Nitrogen inputs elicit a prompt response by the vegetative cover, but since they become depleted over time, pernicious weed species may take over in a natural colonisation processes (Claassen and Carey, 2006; Pedrol et al., 2010; Borden and Black, 2011). Evidence of positive nitrate effects in the medium period on clay spoils has been reported by Bagnaresi et al. (1992).

This study was aimed to evaluate the effect of several strategies (alone or mixed) on soil reclamation and revegetation of abandoned mineral clay quarry sites. In detail, we tested the effect of nitrogen and phosphorous supply, the addition of organic matter and the effect of a clay topsoil blend. The latter represents an original strategy that, for as we know, was never tested on clay soils. The hypothesis was that the inclusion of topsoil to the superior clay substrate may: i) generate a sufficiently deep root-explorable layer, adequate to support a stable vegetation cover and to limit erosion. The detrimental consequences of a shallow root-explorable layer have been described in Schoenholtz et al. (1992); ii) ameliorate the physico-chemical features of the layer explored by roots; iii) bring a microbiological inoculum useful to sustain vegetation cover (Claassen and Zasoski, 1993).

The experimental procedure entailed three linked steps: to prepare the site with inputs of nutrients, organic amendments and limited volumes of recycled on-site soils, to establish a stable grass cover and to assess quantitatively the interaction and effectiveness of the inputs and cover in a reconstructive framework (Sawatsky et al., 2000). In the given time window, such a cover should thus be able to prevent run-off erosion and to elicit the onset of an ecological succession capable of restoring the biological, environmental and landscape functions of these degraded sites. The results of this study might contribute to define reclamation strategies for clay spoils with deficient topsoil layer.

\section{Materials and methods}

\section{Experimental site}

The experimental site is a quarry owned by Sibelco Italia s.p.a. and located at Colombara, a hamlet on the Lavino winterbourne (44 $24 ' 22$ " $\mathrm{N}, 11^{\circ} 10^{\prime} 18^{\prime \prime}$ E) near the town of Monte San Pietro, Bologna province, facing West-Northwest at an elevation of $150 \mathrm{~m}$ a.s.l. The mean longterm yearly rainfall does not exceed $870 \mathrm{~mm}$ (Table 1). The mean across-trial rainfall rate per annum was $863.27 \mathrm{~mm}$ with yearly fluctuations ranging from respective minimums of 571 and $576 \mathrm{~mm}$ in 1998 and 2000 and maximums of 1078 and $994 \mathrm{~mm}$ in 1994 and 1996.

The microclimate of area surrounding the trial is favourable to mixed broadleaf woodland of oak (Quercus pubescens Wild.), along with ash (Fraxinus ornus L.), hornbeam (Ostrya carpinifolia Scop.) and maple (Acer campestre L.).

The test plots were established in the abandoned pit by re-terracing several strips of previously dumped mineral-clay soil (Table 2). The substrate was a mixture of red beds and greenish-gray clays.

\section{Experimental design}

The trial layout consisted of randomised blocks with three replicates; each block was placed on one of the re-terraced horizontal strips. Four input treatments to establish the grass cover directly on the clay soil were tested: slow-release nitrogen $(\mathrm{N})$ organic fertiliser (Biosol®, 6\% $\mathrm{N}$ ), phosphate fertiliser (perphosphate, 21\% $\mathrm{P}_{2} \mathrm{O}_{5}$ ), organic amendment such as dried pellets of cattle manure $(3 \% \mathrm{~N})$, and shallow topsoil. The top $20 \mathrm{~cm}$ of the latter was excavated with a power shovel from a meadow across the quarry that had not been farmed in twenty years. The soil was sieved (mesh $20 \times 20 \mathrm{~mm}$ ) to eliminate rocky and bulky plant mate-

Table 1. Pluviometric data of Monte San Pietro station (246 m a.s.l.).

\begin{tabular}{lcccccccccccccc} 
Year & Jan & Feb & Mar & Apr & May & June & July & Aug & Sept & Oct & Nov & Dec & Tot \\
1994 & 52 & 29 & 1 & 163 & 78 & 224 & 32 & 18 & 292 & 75 & 72 & 22 & 1078 \\
1995 & 10 & 75 & 33 & 25 & 104 & 227 & 48 & 120 & 57 & 46 & 81 & 84 & 910 \\
\hline 1996 & 68 & 60 & 56 & 104 & 80 & 69 & 6 & 57 & 101 & 212 & 78 & 103 & 994 \\
1997 & 73 & 18 & 42 & 57 & 20 & 78 & 41 & 60 & 35 & 34 & 102 & 106 & 666 \\
\hline 1998 & 29 & 27 & 46 & 30 & 61 & 48 & 59 & 21 & 94 & 61 & 16 & 79 & 571 \\
1999 & 37 & 58 & 27 & 82 & 51 & 83 & 5 & 95 & 38 & 77 & 240 & 70 & 863 \\
\hline 2000 & 9 & 2 & 47 & 56 & 12 & 82 & 79 & 26 & 22 & 105 & 82 & 54 & 576 \\
2001 & 72 & 36 & 75 & 101 & 83 & 46 & 60 & 40 & 93 & 38 & 86 & 13 & 743 \\
\hline 2002 & 17 & 70 & 5 & 125 & 76 & 29 & 109 & 128 & 99 & 69 & 67 & 137 & 931 \\
2003 & 55 & 9 & 40 & 132 & 15 & 37 & 0 & 71 & 55 & 105 & 190 & 55 & 764 \\
\hline 2004 & 70 & 150 & 74 & 93 & 46 & 33 & 34 & 8 & 49 & 108 & 141 & 114 & 920 \\
Mean & 44.7 & 48.6 & 40.6 & 88.0 & 56.9 & 88.7 & 43.0 & 58.6 & 85.0 & 84.6 & 105.0 & 76.1 & 819.6 \\
\hline Mean 1926-04 & 56.9 & 57.5 & 68.8 & 82.8 & 80.5 & 67.6 & 46.5 & 54.6 & 75.1 & 100.6 & 97.4 & 75.1 & 863.3 \\
\hline
\end{tabular}


rial and then spread in a layer of $5 \mathrm{~cm}$, a notably shallower depth than 30-100 cm topsoil range reported elsewhere (Halvorson and Doll, 1985; Schuman et al., 2000; Bowen et al., 2005). Yet the purpose of this study was to spur the onset of the biological activity normally present in topsoil layers (Bellgard, 1993) and not to recreate a new topsoil horizon for plant life. Compared to previous trials (Bagnaresi et al., 1992; Muzzi et al., 1997), the amount of agronomic inputs was restricted in order to limit the impact on the topsoil properties.

The trial presented a $2^{4}$ layout with each treatment in two distinct levels: i) slow-release $\mathrm{N}$ : Biosol® (N) $0-100 \mathrm{~g} \mathrm{~m}^{-2}$ of $\mathrm{N}\left(60 \mathrm{~kg} \mathrm{ha}^{-1}\right)$; ii) phosphorous: triple perphosphate (P) $0-20 \mathrm{~g} \mathrm{~m}^{-2}$ of $\mathrm{P}_{2} \mathrm{O}_{5}\left(200 \mathrm{~kg} \mathrm{ha}^{-1}\right)$; iii) organic amendment: manure pellets (OM) $0-200 \mathrm{~g} \mathrm{~m}^{-2}$ of organic matter (2000 kg ha-1); iv) on-site topsoil: (S) 0-0.05 m (500 m $\left.\mathrm{ha}^{-1}\right)$.

Each block contained 16 plots and covered $20 \mathrm{~m}^{2}(4 \times 5 \mathrm{~m})$.

\section{Experiment setup and follow-up}

Spring 1993: after experimental area was delimitated, topsoil and fertilisers were spread on the plots and the blocks were harrowed to aerate the substrate and provide a minimal connection between topsoil and mineral clay. By superficial tilling $(0.20 \mathrm{~m})$, the topsoil and the nutrients were then mixed with the mineral clay. A final soil milling improved the seedbed.

Grasses and legumes $\left(26 \mathrm{~g} \mathrm{~m}^{-2}\right)$ in a mix of matching proportions were sown: i) legumes: Vicia villosa Roth. (1.00\%); Medicago lupulina L. (7.00\%); Hedysarum coronarium L. (7.00\%); Lotus corniculatus L. (25.00\%); Melilotus alba L. (5.00\%); Melilotus officinalis L. (5.00\%); grasses: Alopecurus myosuroides Huds. (3.00\%); Lolium perenne L. (2.00\%); Dactylis glomerata L. (11.00\%); Cynodon dactylon L. (25.00\%); Agropyron repens (L.) P. Beauv. (4.00\%); Schedonorus arundinaceous (Schreb.) Dumort (5.00\%).

Sowing occurred on 12 September 1993 by manual broadcasting and the seeds were manually raked into the soil.

Daily microclimatic data (air temperatures and rainfall) were recorded for the whole trial duration by a weather station placed at the Monte S. Pietro, within $2 \mathrm{~km}$ from the experimental site.

Starting from January 1994 until 2004, when slope-instability compromised plot integrity, the three blocks percentage of the vegetative cover (Braun-Blanquet, 1964; Di Tommaso, 1992) was visually estimated monthly by the same person.

\section{Statistical analysis}

The daily rainfall recorded by the weather station were reprocessed per quarter and correlated to the mean percentage of the grass coverage of June and December (Table 3).

June percentage of the fractions of vegetation cover, for all available years, were initially used to analyse the trial layout via Proc Glimmix (The SAS System for Windows, Release 9.0.; 2002. SAS Institute Inc., Cary, NC, USA) for binomial data repeated over years as follows: i) years as repeated factor, after autoregressive order 1 covariance correction; ii) blocks as random factor; iii) treatments $\left(2^{4}=16\right)$ as fixed factor.
The same June percentage of the vegetation cover data, were then transformed using the Bliss formula (Steel and Torrie, 1980) and the results analysed using Proc Mixed (The SAS System for Windows, Release 9.0.; 2002. SAS Institute Inc., Cary, NC, USA) while retaining the same structure of Repeated Measures. The results of both analyses were compared against the Akaike's information criterion (AIC) index (Table 4). The statistic significance of treatments and their interactions (Table 5) were evaluated through contrasts of Proc Mixed (Davidian, 2005). Standardised effects of the treatments were calculated using the inverse transformation of means (Montgomery, 1997) (Table 5).

\section{Results and discussion}

Comparing the mean vegetation cover fractions of June and December, i.e., respective maximum and minimum windows of biological activity, against yearly rainfall evinces a positive correlation: $+0.562(\mathrm{r}) / 0.473(\rho)$ for June and $+0.631(\mathrm{r}) / 0.542(\rho)$ for December (Table 3). A maximum positive correlation was also found between June and December vegetation cover data and rainfall in the second quarter $[0.766(\mathrm{r}) / 0.638(\rho)$ and $0.750(\mathrm{r}) / 0.776(\rho)$ respectively].

Vegetation cover composition was dominated by grass species, namely Lolium perenne L. in the first year, then replaced by Elymus

Table 2. Chemical composition of tested clay substrates.

\begin{tabular}{|c|c|c|c|}
\hline & & $\begin{array}{l}\text { rofile } \\
\text { Mineral }\end{array}$ & Topsoil \\
\hline Sand & $\%$ & 36.0 & 24.0 \\
\hline Loam & $\%$ & 37.0 & 51.0 \\
\hline Clay & $\%$ & 27.0 & 25.0 \\
\hline $\mathrm{pH}\left(\mathrm{H}_{2} \mathrm{O}\right)$ & & 9.69 & 8.21 \\
\hline Total lime & g $100 g^{-1}$ & 2.00 & 12.0 \\
\hline Active lime & g $100 \mathrm{~g}^{-1}$ & 1.60 & 8.80 \\
\hline CEC & Meq $100 \mathrm{~g}^{-1}$ & 23.7 & 26.2 \\
\hline $\mathrm{Ca}$ & $\mathrm{mg} \mathrm{kg}^{-1}$ & 2048 & 4406 \\
\hline $\mathrm{Mg}$ & $\mathrm{mg} \mathrm{kg}^{-1}$ & 734 & 353 \\
\hline K & $\mathrm{mg} \mathrm{kg}^{-1}$ & 411 & 280 \\
\hline $\mathrm{Na}$ & $\mathrm{mg} \mathrm{kg}^{-1}$ & 1472 & 134 \\
\hline $\mathrm{OM}$ & g $100 g^{-1}$ & 0.44 & 2.15 \\
\hline Total N & $\mathrm{g} \mathrm{kg}^{-1}$ & 0.33 & 1.70 \\
\hline $\mathrm{C} / \mathrm{N}$ & & 7.73 & 7.34 \\
\hline
\end{tabular}

CEC, cation exchange capacity; Ca, calcium; Mg, magnesium; K, potassium; Na, sodium; OM, organic matter; N, nitrogen; C, carbon.

Table 3. Rainfall-Grass cover correlation.

\begin{tabular}{lcccc} 
& \multicolumn{2}{c}{ June grass cover } & \multicolumn{2}{c}{ December grass cover } \\
Coefficient correlation & r Pearson & $\rho$ Spearman & r Pearson & 0.631 \\
Average yearly rainfall & 0.562 & 0.473 & 0.098 & 0.542 \\
$1^{\text {st }}$ quarter rainfall & 0.090 & -0.100 & 0.750 & 0.196 \\
\hline $2^{\text {nd }}$ quarter rainfall & 0.766 & 0.638 & 0.218 & 0.776 \\
$3^{\text {rd }}$ quarter rainfall & - & - & 0.055 & 0.310 \\
\hline $4^{\text {th }}$ quarter rainfall & - & - & 050 \\
\hline
\end{tabular}


repens (L.) Gould and Schedonorus arundinaceous (Schreb.) Dumort.

The June vegetation cover, after a maximum mean value of $75 \%$ in the second year, was evaluated of $60 \%$ for all following years (Figure 1). This trend is in agreement with a previous study (Roberts et al., 1988), and may be dependent on the progressive mineralisation of the added organic matter, which occurs in absence of other $\mathrm{N}$ sources (e.g., $\mathrm{N}$ fixation). A clear effect of treatments on herbaceous cover is apparent for the first seven years (Figure 1); thereafter, the gap between control and treatments is reduced by the spread of a native pioneer species (e.g., Dittrichia viscosa (L.) Greuter).

Analysis of variance for vegetation cover shows a clearly lower AIC vis-à-vis Glimmix's, the reason for having proceeded with the subsequent comparisons. The Table of variance in Table 4 shows a significant interaction of all treatments with time. All interactions between treatments were not significant, except for $\mathrm{N} \times 0 \mathrm{M}[\mathrm{p}(\mathrm{F})=0.04]$. A pos-

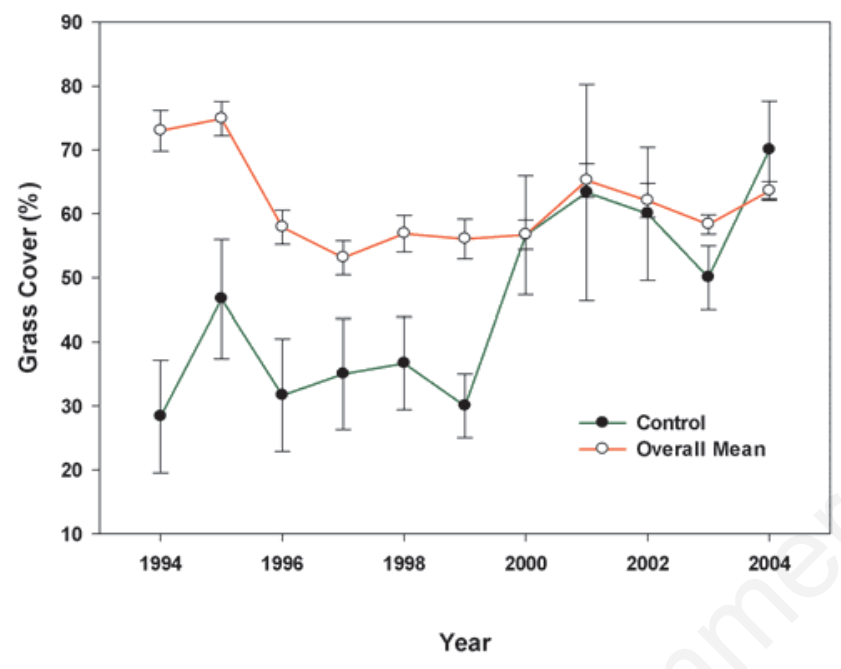

Figure 1. Mean of total grass cover and of control over Years (mean \pm standard error of the mean).

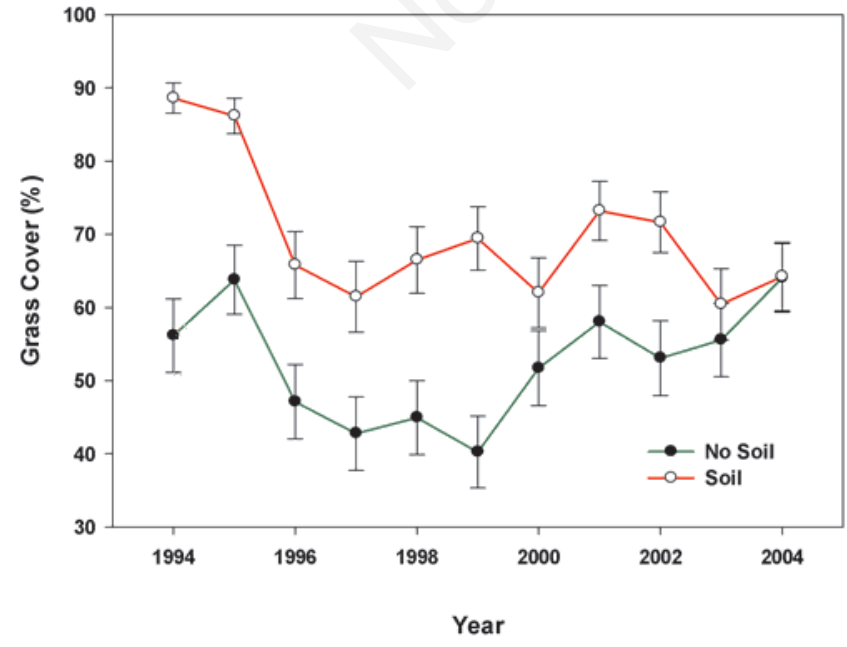

Figure 2. Plot of grass cover as Year $\times$ Soil interaction (mean \pm standard error of the mean). itive interaction between topsoil and chemical fertiliser (NPK) was found by Richardson and Evans (1986); by contrast, no significance were detected by McGinnies and Nicholas (1980), and by Sydnor and Redente (2000).

Richardson and Evans (1986) and Beauchamp et al. (2006) determined a significant $\mathrm{N} \times 0 \mathrm{M}$ interaction (or chemical fertiliser $\times$ organic matter), while no significant results were reported in Heeraman et al. (2001). In the present study, the absence of interactions between treatments may be partially attributed to the vegetation cover values expressed in percentage: they have a high (Beauchamp et al., 2006) minimum detectable difference (Zar, 1984), which can mask weak effects. The standardised effect of all treatments in Table 5 confirmed the temporal trends supra and provided a precise quantification over time of the individual treatment effects and of their interactions.

A significant contribution of topsoil to vegetation cover was deter-

Table 4. Analysis of variance for both analysis methods employed.

\begin{tabular}{|c|c|c|c|c|}
\hline \multicolumn{5}{|c|}{ Anova repeated measures analysis* } \\
\hline Effect & F value & $\operatorname{Pr}>\mathrm{F}$ & F value & $\operatorname{Pr}>\mathrm{F}$ \\
\hline Year & 25.40 & $<0.0001$ & 24.81 & $<0.0001$ \\
\hline Soil & 65.90 & $<0.0001$ & 58.46 & $<0.0001$ \\
\hline $\mathrm{Y} \times \mathrm{S}$ & 11.17 & $<0.0001$ & 9.80 & $<0.0001$ \\
\hline $\mathrm{N}$ & 0.80 & 0.37 & 0.56 & 0.46 \\
\hline $\mathrm{Y} \times \mathrm{N}$ & 2.10 & 0.02 & 2.14 & 0.02 \\
\hline $\mathrm{S} \times \mathrm{N}$ & 0.33 & 0.57 & 0.20 & 0.66 \\
\hline $\mathrm{Y} \times \mathrm{S} \times \mathrm{N}$ & 0.60 & 0.81 & 0.67 & 0.75 \\
\hline Phosphorus & 16.58 & $<0.0001$ & 15.89 & $<0.0001$ \\
\hline $\mathrm{Y} \times \mathrm{P}$ & 2.07 & 0.03 & 2.21 & 0.02 \\
\hline $\mathrm{S} \times \mathrm{P}$ & 0.85 & 0.36 & 0.31 & 0.58 \\
\hline $\mathrm{Y} \times \mathrm{S} \times \mathrm{P}$ & 0.83 & 0.60 & 0.73 & 0.69 \\
\hline $\mathrm{N} \times \mathrm{P}$ & 0.24 & 0.62 & 0.22 & 0.64 \\
\hline $\mathrm{Y} \times \mathrm{N} \times \mathrm{P}$ & 1.38 & 0.19 & 1.33 & 0.21 \\
\hline $\mathrm{S} \times \mathrm{N} \times \mathrm{P}$ & 0.04 & 0.84 & 0.15 & 0.69 \\
\hline $\mathrm{Y} \times \mathrm{S} \times \mathrm{N} \times \mathrm{P}$ & 1.11 & 0.36 & 1.22 & 0.27 \\
\hline Organic matter & 21.97 & $<0.0001$ & 18.78 & $<0.0001$ \\
\hline $\mathrm{Y} \times \mathrm{OM}$ & 5.25 & $<0.0001$ & 4.44 & $<0.0001$ \\
\hline $\mathrm{S} \times \mathrm{OM}$ & 0.13 & 0.72 & 0.61 & 0.44 \\
\hline $\mathrm{Y} \times \mathrm{S} \times \mathrm{OM}$ & 0.68 & 0.74 & 0.76 & 0.66 \\
\hline $\mathrm{N} \times \mathrm{OM}$ & 3.95 & 0.05 & 4.34 & 0.04 \\
\hline $\mathrm{Y} \times \mathrm{N} \times \mathrm{OM}$ & 1.23 & 0.27 & 1.56 & 0.12 \\
\hline $\mathrm{S} \times \mathrm{N} \times \mathrm{OM}$ & 3.06 & 0.08 & 3.28 & 0.07 \\
\hline $\mathrm{Y} \times \mathrm{S} \times \mathrm{N} \times \mathrm{OM}$ & 0.99 & 0.45 & 1.03 & 0.42 \\
\hline $\mathrm{P} \times \mathrm{OM}$ & 1.11 & 0.29 & 1.20 & 0.28 \\
\hline $\mathrm{Y} \times \mathrm{P} \times \mathrm{OM}$ & 1.47 & 0.15 & 1.46 & 0.15 \\
\hline $\mathrm{S} \times \mathrm{P} \times \mathrm{OM}$ & 0.17 & 0.68 & 0.28 & 0.59 \\
\hline $\mathrm{Y} \times \mathrm{S} \times \mathrm{P} \times \mathrm{OM}$ & 1.16 & 0.32 & 1.00 & 0.45 \\
\hline $\mathrm{N} \times \mathrm{P} \times \mathrm{OM}$ & 0.82 & 0.37 & 1.16 & 0.28 \\
\hline $\mathrm{Y} \times \mathrm{N} \times \mathrm{P} \times \mathrm{OM}$ & 1.13 & 0.34 & 1.13 & 0.34 \\
\hline $\mathrm{S} \times \mathrm{N} \times \mathrm{P} \times \mathrm{OM}$ & 2.29 & 0.13 & 2.40 & 0.12 \\
\hline $\mathrm{Y} \times \mathrm{S} \times \mathrm{N} \times \mathrm{P} \times \mathrm{OM}$ & 1.32 & 0.22 & 1.26 & 0.25 \\
\hline AIC & & & -39 & \\
\hline
\end{tabular}

*Significant P-values are reported in italics. Y, year; S, soil; N, nitrogen; P, perphosphate; OM, organic matter; AIC, Akaike's information criterion index. 
mined over approximately 10 years from sowing (Figure 2 and Table 5). This result agrees with Richardson and Evans (1986), and Schwenke $e t$ al. (1999), where topsoil was mixed with the mineral substrate; however, both cited studies were of short duration (1-2 years) and could not provide the observation over time. In the present survey, the effect of topsoil tended to decline over time, from $31.4 \%$ in 1994 to $0.10 \%$ in 2004 (Table 5).

$\mathrm{N}$ did not explicate a significant effect, with values ranging from $8.16 \%$ in 1994 to $-0.17 \%$ in 2004 (Figure 3 and Table 5). Also Richardson and Evans (1986) did not determine substantial effects of chemical fertilisation, even using a triple NPK fertiliser (12-18-12); vice versa, McGinnies and Nicholas (1980) found a significant effect of $\mathrm{N}$ at higher doses (112 $\mathrm{kg} \mathrm{ha}^{-1}$ ), compared with the present experiment, and in a short period (2 year).

P see-sawed over time: its effect was notable the first year, then vanished for about 5 years and notably resurged towards the end of the trial (Figure 4 and Table 5). P effect varied from $13.2 \%$ in 1994 to $6.1 \%$ in 2004, and reached its maximum of 14.1\% in 2001 (Table 5). Richardson and Evans (1986) and Heereaman et al. (2001) did not find significant effects using $P$ in short-term experiments.

The effects of the organic amendment went from $26.2 \%$ in 1994 to $0.8 \%$ in 2004 , resulting significant in early years and gradually tapering off after year 7 (Figure 5). These findings match the results gained from corresponding tests performed both in short (Heereman et al., 2001; Beauchamp et al., 2006; Claassen and Carey, 2006; Grigg et al., 2006; 0'Dell and Claassen, 2006; Curtis and Claassen, 2009) and medium periods (Roberts et al., 1988).

\section{Conclusions}

First and foremost, overall data show the notably significant acrosstrial effectiveness of the topsoil, even in the minimal volume applied, on the grass cover. This input likely improved the physical and chemical properties of the mineral-clay substrate as well as to spur the onset of biological elements, from enzymes to seed, that primed the cover's prompt and lasting response. The other inputs (N, $\mathrm{P}$ and $\mathrm{OM})$ showed

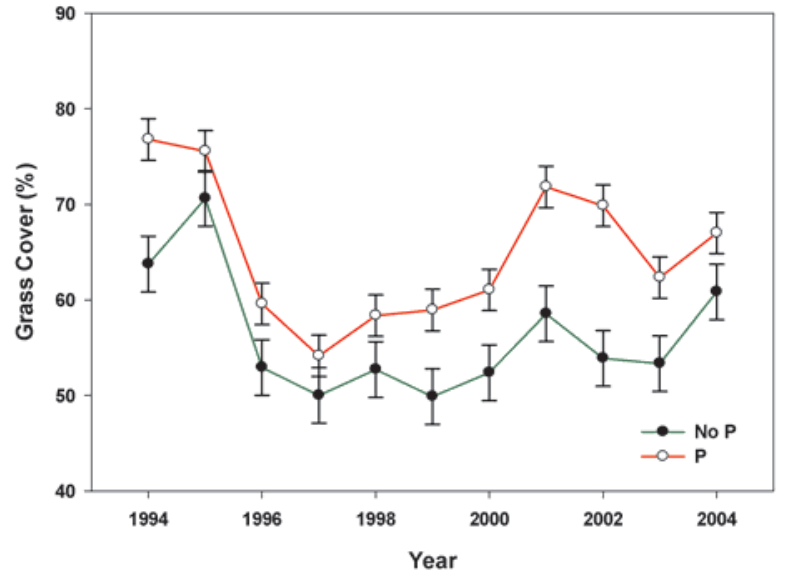

Figure 4. Plot of grass cover as Year $\times \mathrm{P}$ (phosphorus) interaction (mean \pm standard error of the mean).

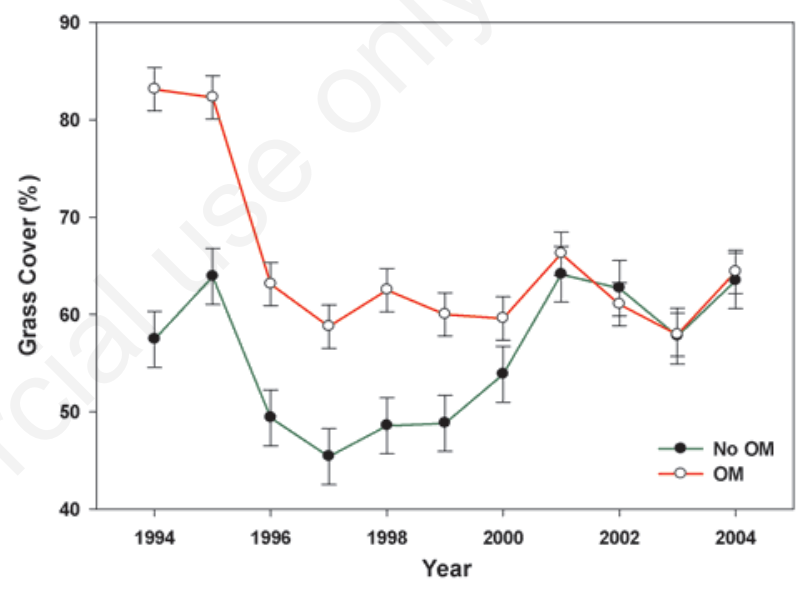

Figure 5. Plot of grass cover as of the Year $\times$ Organic matter $(\mathrm{OM})$ interaction (mean \pm standard error of the mean).

Table 5. Standardised effects of treatments and their interaction over time.

\begin{tabular}{lccccccccccc} 
Treatments & 1994 & 1995 & 1996 & 1997 & 1998 & 1999 & 2000 & 2001 & 2002 & 2003 & 2004 \\
Soil & 31.45 & 23.23 & 18.82 & 19.26 & 22.08 & 29.55 & 10.68 & 15.41 & 18.80 & 4.97 & 0.10 \\
$\mathrm{~N}$ & 8.16 & 9.01 & 8.62 & 4.23 & 6.94 & -0.55 & -5.76 & -3.97 & -7.32 & -1.12 & -0.17 \\
\hline Phosphorus & 13.20 & 4.73 & 7.01 & 4.77 & 6.39 & 10.60 & 9.53 & 14.09 & 17.26 & 9.27 & 6.08 \\
Organic matter & 26.21 & 18.82 & 14.54 & 14.33 & 14.74 & 12.66 & 6.29 & 2.25 & -1.48 & 0.16 & 0.83 \\
\hline $\mathrm{P} \times \mathrm{OM}$ & -11.85 & -5.30 & -3.93 & -3.89 & -1.65 & -1.47 & -4.33 & 3.12 & -1.32 & 0.84 & 0.03 \\
$\mathrm{~N} \times \mathrm{OM}$ & -3.70 & 2.59 & 4.75 & 6.12 & 3.50 & 4.71 & 11.67 & 8.55 & 3.65 & 3.53 & 6.43 \\
\hline $\mathrm{S} \times \mathrm{OM}$ & -9.72 & -7.44 & -4.02 & -3.02 & -4.26 & 1.10 & 1.93 & -1.79 & -2.81 & 0.97 & 1.79 \\
$\mathrm{~N} \times \mathrm{P}$ & -0.27 & 0.28 & -2.89 & -2.58 & -2.40 & -6.16 & -1.50 & 0.35 & 3.66 & -4.26 & 2.44 \\
\hline $\mathrm{S} \times \mathrm{P}$ & -2.00 & 1.52 & 4.74 & 4.46 & 3.24 & 4.02 & -1.04 & -2.67 & 0.73 & -2.71 & -1.90 \\
$\mathrm{~S} \times \mathrm{N}$ & -3.59 & -6.37 & -4.53 & -0.89 & -1.04 & -2.29 & 0.57 & 0.18 & 2.24 & -0.89 & 3.45 \\
\hline $\mathrm{S} \times \mathrm{N} \times \mathrm{P}$ & -4.01 & 1.70 & 2.55 & 0.68 & 0.12 & 1.65 & -5.08 & -4.35 & -1.33 & -3.50 & 1.55 \\
$\mathrm{~S} \times \mathrm{N} \times \mathrm{OM}$ & -1.89 & -7.10 & -1.24 & -4.19 & -6.65 & -4.87 & -6.39 & -6.42 & -2.43 & -1.71 & -3.68 \\
\hline $\mathrm{S} \times \mathrm{P} \times \mathrm{OM}$ & -3.22 & 0.49 & -0.17 & 3.05 & 1.49 & 6.20 & 2.64 & 0.13 & -0.26 & 2.75 & 1.68 \\
$\mathrm{~N} \times \mathrm{OM} \times \mathrm{P}$ & 1.59 & -3.86 & -11.40 & -6.93 & -3.17 & -5.04 & -3.23 & 2.92 & 4.76 & -4.58 & 1.85 \\
\hline $\mathrm{S} \times \mathrm{N} \times \mathrm{OM} \times \mathrm{P}$ & -1.83 & 7.41 & 10.01 & 7.09 & 5.95 & 11.97 & 1.52 & -0.70 & 1.85 & 1.57 & -0.80 \\
\hline
\end{tabular}

*Significant $\mathrm{P}$-values $(\mathrm{P}<0.05)$ are reported in italics. $\mathrm{N}$, nitrogen; $\mathrm{P}$ perphosphate; $\mathrm{OM}$, organic matter; $\mathrm{S}$, soil. 
results limited over time.

In a more general view, the reconstructive approach we employed evinced its practical and biological limits over the 10 years trial. Treatment effects gradually faded, compromising in part the vegetative response as the cover's effectiveness in checking erosion from run-off of heavy rainfall considerably weakened over time. In fact, as the midterm trend of control corroborates, the cover's thinning laid bare swaths of the substrate after 6 years and allowed colonising species to invade and spread. A reappraisal of approach to this kind of reclamation is thus in order so as to make greater and better, more fundamental use of original site substrates.

\section{References}

Bagnaresi U, Ferrari C, Muzzi E, Rossi G, 1992. Ricerche sulla sistemazione a verde di una cava di argilla (Appennino Reggiano). Comune di Carpineti, Carpineti, Reggio Emilia, Italy.

Baines JC, 1989. Choices in habitat re-creation. In: G.P. Buckley (Ed.), Biological habitat reconstruction. John Wiley and Sons, Chichester, UK.

Beauchamp CJ, Camiré C, Chalifour FP, 2006. Use of bark and combined paper sludge for the revegetation of bark covered land. J. Environ. Eng. Sci. 5:253-61.

Bellgard SE, 1993. The topsoil as the major store of the propagules of vesicular arbuscular mycorrhizal fungi in Southeast Australian sandstone soils. Mycorrhiza 3:19-24.

Borden RK, Black R, 2011. Biosolids application and long-term noxious weed dominance in western United States. Restor. Ecol. 19:639-47.

Bowen CK, Schuman GE, Olson RA, Ingram LJ, 2005. Influence of topsoil depth on plant and soil attributes of 24 year old reclaimed lands. Arid Land Res. Manag. 19:267-84.

Braun-Blanquet J, 1964. Pflanzensoziologie. Springer, Vienna, Austria.

Claassen VP, Carey JL, 2006. Comparison of slow-release nitrogen yield from organic soil amendments and chemical fertilizers and implications for regeneration of disturbed sites. Land Degrad. Dev. 18:119-32.

Claassen VP, Zasoski RJ, 1993. Enhancement of vegetation on construction fill by fertilizer and topsoil application: effect on mycorrhizal infection. Land Degrad. Dev. 4:45-57.

Cockrell JR, Biondini ME, Kirby D, 1993. Vesicular arbuscular mycorrhizal recolonization of grasses on a reclaimed stripmine in North Dakota. Prairie Nat. 35:161-71.

Curtis MJ, Claassen VP, 2009. Regenerating top soil functionality in four drastically disturbed soil types by compost incorporation. Restor. Ecol. 17:24-32.

Davidian M, 2005. Applied longitudinal data analysis. Lecture notes: North Carolina State University, CA, USA, pp 208-308.

Di Tommaso PL, 1992. Geobotanica. CUSL, Firenze, Italy.

Grigg AH, Sheridan GJ, Pearce AB, Mulligan DR, 2006. The effect of organic mulch amendments on the physical and chemical properties and revegetation success of a saline-sodic minespoil from central Queensland, Australia. Aust. J. Soil Res. 44:97-105.

Haigh MJ, 2000. The aim of land reclamation. In: M.J. Haig (Ed.), Reclaimed land. Erosion control, soil ecology. AA Balkema, Rotterdam, the Netherlands, pp 1-20.

Halvorson GA, Doll EC, 1985. Topsoil and subsoil replacement on stripmined land in North Dakota, USA. pp 232-241 in Proc. Bridging the Gap Between Science, Regulation, and the Surface Mining Operation, Second Annual Meeting, American Society of Surface Mining and Reclamation, Denver, C0, USA.

Heeraman DA, Claassen VP, Zasoski RJ, 2001. Interaction of lime, organic matter and fertilizer on growth and uptake of arsenic and mercury by Zorro fescue (Vulpia myuros L.). Plant Soil. 234:215-31.

Hodgson JG, 1995. Selecting and managing plant materials used in habitat construction. In: G.P. Buckley (Ed.), Biological habitat reconstruction. John Wiley and Sons, Chichester, UK, pp 45-67.

Hume LJ, August JA, 1988. Effects of phosphorus application and mycorrhizal inoculation on white clover (Trifolium repens) growth in andesite tailings from Martha Mine, Waihi. New Zeal. J. Agr. Res. 31:331-8.

Koide RT, Mooney HA, 1987. Revegetation of serpentine substrates: response to phosphate application. Environ. Manage. 11:563-7.

Legambiente, 2014. Rapporto Cave 2014. Legambiente, Roma, Italy.

Marrs RH, Gough MW, 1995. Soil fertility-a potential problem for habitat restoration. In: Buckley GP (Ed.), Biological habitat reconstruction. John Wiley and Sons, Chichester, UK, pp 29-44.

Mays DA, Sistani KR, Soileau JM, 2000. Lime and fertilizer needs for land reclamation. In: R.I. Barnhisel, R.G. Darmody, W.L. Daniels (Eds.), Reclamation of drastically disturbed lands. American Society of Agronomy, Crop Science Society of America, Soil Science Society of America, Madison, WI, USA, 41:217-40.

McGinnies WJ, Nicholas PJ, 1980. Effects of topsoil thickness and nitrogen fertilizer on the revegetation of coal mine spoils. J. Environ. Qual. 9:681-5.

Montanari V, 2012. Piastrelle italiane di ceramica: elementi di cronologia 1900-2012. Casalgrande Alto, Reggio Emilia, Italy.

Montgomery DG, 1997. Design and analysis of experiments. John Wiley and Sons, New York, NY, USA.

Morgan RPC, 1986. Soil erosion and conservation. Longman, New York, NY, USA.

Muzzi E, Roffi F, Sirotti M, Bagnaresi U, 1997. Revegetation techniques on clay soil slopes in Northern Italy. Land Degrad. Dev. 8:127-37.

Muzzi E, Rossi G, 2003. Il recupero e la riqualificazione ambientale delle cave in Emilia Romagna. Regione Emilia Romagna, Bologna, Italy.

0'Dell RE, Claassen VP, 2006. Vertical distribution of organic amendment influences the rooting depth of revegetation species on barren, subgrade serpentine substrate. Plant Soil 285:19-29.

Pedrol N, Puig CG, Souza P, Forjàn R, Vega FA, Asensio V, Gonzalez L, Cerqueira B, Covelo EF, Andrace L, 2010. Soil fertility and spontaneous revegetation in lignite spoil banks under different amendments. Soil Tillage Res. 110:134-42.

Pesant AR, Vigneux A, 1992. Restoring productivity to artificially eroded soils with the use of beef cattle manure. In: H. Hurni, K. Tato (Eds.), Erosion, conservation and small scale farming. Geographica Bernensia, Berne, Switzerland, pp 431-8.

Redente EF, Depuit EJ, 1988. Reclamation of drastically disturbed rangelands. In: P.T. Tueller (Ed.), Vegetation science applications for rangeland analysis and management. Kluwer Acc. Press, Dordrecht, the Netherlands. pp 561-84.

Reeder JD, McGinnies J, 1989. Response of established forages on reclaimed mined land to fertilizer $\mathrm{N}$ and $\mathrm{P}$. J. Range Manage. 42:327-32.

Richardson JA, Evans ME, 1986. Restoration of grassland after magnesian limestone quarrying. J. Appl. Ecol. 23:317-32.

Roberts JA, Daniels WL, Bell JC, Martens DC, 1988. Tall fescue production and nutrient status on southwest Virginia mine soils. J. Environ. Qual. 17:55-62.

Sawatsky L, McKenna G, Keys MJ, Long D, 2000. Toward minimizing the long term liability of reclaimed mine sites. In: M.J. Haig (Ed.), Reclaimed land. Erosion control, soil ecology. AA Balkema, Rotterdam, the Netherlands, pp 21-36.

Schoenholtz SH, Burger J, Kreh KE, 1992. Fertilizer and organic amendment effects on mine soil properties and revegetation suc- 
cess. Soil Sci. Soc. Am. J. 56:1177-84.

Schuman GE, Smith JA, King LA, 2000. Reclamation of bentonite mined land. In: R.I. Barnhisel, R.G. Darmody, W.L. Daniels (Eds.), Reclamation of drastically disturbed lands. American Society of Agronomy, Crop Science Society of America, Soil Science Society of America, Madison WI, USA, 41:687-708.

Schwenke GD, Mulligan DR, Bell LC, 1999. Soil stripping and replacement for the rehabilitation of bauxite-mined land at Weipa. I. Initial changes to soil organic matter and related parameters. Aust. J. Soil Res. 38:345-69.

Steel RGD, Torrie JH, 1980. Principles and procedures of statistics: a biometrical approach. McGraw-Hill Kogakusha, Tokyo, Japan. Sydnor RS, Redente EF, 2000. Long term plant community development on top soil treatments overlying a phytotoxic growth medium. J. Environ. Qual. 29:1778-86.

Tate RL III, 1985. Microorganisms, ecosystem disturbance and soil formation processes. In: R.L. Tate III, D.A. Klein (Eds.), Soil reclamation processes. Microbiological Analyses and Applications. Marcel Dekker inc., New York, NY, USA, pp 1-33.

Zar JH, 1984. Biostatistical Analysis. Prentice-Hall International Inc., Englewood Cliffs, NJ, USA. 